\title{
Adsorption of Methylene Blue and Methyl Orange By Using Waste Ash
}

\author{
Serpil SAVCI ${ }^{* 1}$, Mehmet Mert UYSAL ${ }^{1}$
}

${ }^{1}$ Bozok University, Engineering and Architecture Faculty, Biosystems Engineering Department, 66100, Yozgat

(Alınış / Received: 31.01.2017, Kabul / Accepted: 09.09.2017, Online Yayınlanma / Published Online: 13.10.2017)

Keywords

Waste ash,

Isotherm,

Desorption

\begin{abstract}
The adsorption in a batch system for methylene blue (MB) and methyl orange (MO) on waste ash were evaluated. The adsorption isotherms showed adsorptive maximum capacities for waste ash of MB and MO $40.983 \mathrm{mg} \mathrm{g}^{-1} 35.614$ $\mathrm{mg} \mathrm{g}^{-1}$ respectively. The equilibrium adsorption data were fitted by DubininRadushkevic (D-R) adsorption isotherm model. The estimated values of adsorption energy, Ea, calculated from the D-R isotherm, for both MB and MO and waste ash systems were found to be $0.015 \mathrm{~kJ} \mathrm{~mol}^{-1}, 0.091 \mathrm{~kJ} \mathrm{~mol}^{-1}$ at room temperature respectively which implies that adsorption of both MB and MO on waste ash $(0.3 \mathrm{~g})$ is by physical adsorption. Waste ash and the dyes loaded waste ash were characterized by SEM. We studied reusability and it was found that the waste ash is stable and regenerable by $5 \mathrm{M} \mathrm{HNO}_{3}$ without losing their activity. This research suggests that the waste ash can be an effective adsorbent for the removal of such acidic and basic dyes from aquatic solution.
\end{abstract}

\section{Atık Kül Kullanılarak Methylene Blue ve Methyl Orange Adsorpsiyonu}

Anahtar Kelimeler

Atık kül,

İzoterm,

Desorpsiyon

\begin{abstract}
Özet: Methylene blue ve Methyl orange'nin atık kül üzerine adsorpsiyonu kesikli bir sistem ile değerlendirilmiştir. Adsorpsiyon izotermleri, attk kül için maximum adsorpsiyon kapasitesini methylene blue ve methyl orange için sırasıyla $40.983 \mathrm{mg}$ $\mathrm{g}^{-1} 35.614 \mathrm{mg} \mathrm{g}^{-1}$ olarak göstermiştir. Dengedeki adsorpsiyon verilerinden Dubinin-Radushkevic (D-R) izoterm modeli de tanımlanmıștır. DubininRadushkevic (D-R) izoterm modelinden hesaplanan adsorpsiyon enerjisi Ea, oda sıcaklığında methylene blue ve methyl orange için sırasıyla $0.015 \mathrm{~kJ} \mathrm{~mol}^{-1}, 0.091 \mathrm{~kJ}$ mol-1 $^{-1}$ olarak hesaplanmıștır. Bu da atık kül üzerine $(0.3 \mathrm{~g})$ methylene blue ve methyl orange adsorpsiyonunun fiziksel adsorpsiyon olduğunu ifade etmektedir. Atık külün boya yüklü ve boya yüksüz görüntüleri SEM ile karakterize edilmiștir. Yeniden kullanılabilirlik çalışmaları da yapılmış ve $5 \mathrm{M} \mathrm{HNO}_{3}$ ile atık külün aktivitesini kaybetmediği ve yenilenebilir olduğu belirlenmiștir. Bu çalışma atık külün sulu çözeltilerden asidik ve bazik boyaların gideriminde etkili bir adsorban olduğunu önermektedir.
\end{abstract}

\section{Introduction}

Considering the run out of water resources in one day, water pollution and control is a very important in recent years. Dyes are one of the most common pollutants in the world. Even though the dyes discharged to the receiving environment constitutes only a small portion of water pollution, it is undesirable, especially in developed countries for aesthetics and ecology. Also, Dyes may spread toxic and carcinogenic metabolites in anaerobic conditions. Dyes can be treated by physical and chemical methods to prevent pollution in the aquatic environment. However, cost of these methods is extremely high. Sludge can be produced in some of these methods. In order to eliminate the color of the wastewater is a need for alternative methods. Adsorption is the most common methods for the removal of dyes from wastewater. In addition to it is well known process to treatment pollutants from aqueous media and investigations have been deeply sustained for the efficient process. Active carbon is the most preferred adsorbent because of high adsorption capacity. In recent days, more economical and environmentally friendly adsorbents have been used instead of activated carbon [1-2]. In this article, adsorption of MB and MO from aqueous solution on waste ash investigated as a function of initial $\mathrm{pH}$ level, initial dye concentration, and contact time by batch system. Langmuir, Freundlich and Dubinin 
Radushkevich isotherm models, kinetic and thermodynamic studies calculated for the adsorption of MB-MO by using waste ash.

\section{Material and Method}

\subsection{Chemicals}

MO $\quad\left(\mathrm{C}_{14} \mathrm{H}_{14} \mathrm{~N}_{3} \mathrm{NaO}_{3} \mathrm{~S}\right.$ molecular weight 327.34 $\mathrm{g} / \mathrm{mol} / \mathrm{l})$ and $\mathrm{MB}\left(\mathrm{C}_{16} \mathrm{H}_{18} \mathrm{~N}_{3} \mathrm{ClS}\right.$ molecular weight $319.85 \mathrm{~g} / \mathrm{mol} / \mathrm{l})$ were selected as an adsorbate. MO and MB were purchased from (Carlo Erba Reagent) Arkim Company in Turkey. Waste ash was obtained from a sugar factory in Yozgat in Turkey. The 1000 ppm stock solution of dye was prepared. Same studies were conducted for MO. The maximum wavelengths are $467 \mathrm{~nm}$ and $665 \mathrm{~nm}$ for MO and MB respectively.

\subsection{Experimental studies}

Adsorption studies were performed in $100 \mathrm{~mL}$ Erlenmeyer Flasks including $0.3 \mathrm{~g}$ of waste ash with $30 \mathrm{~mL}$ of $\mathrm{MB}$ and $\mathrm{MO}$ dye solutions. All the adsorption experiments were done at room temperature $\left(25^{\circ} \mathrm{C}\right)$ via batch method. The solution was shaken by a mechanical shaker (VWR) at the constant agitation time (150 rpm) during 4 hours. Then the supernatant was centrifuged at $4000 \mathrm{rpm}$ and 10 minutes in a centrifuge (Hettich Zentrifugen) after the batch tests. The absorbance's of MB and MO were measured at maximum wavelength by UV-VIS Spectrophotometer (Shimadzu UV 1208).

For the contact time experiments, the initial dye concentrations were varied from 100 to $1200 \mathrm{mg} / \mathrm{L}$. The incubation time was tested in a time from 5 to $240 \mathrm{~min}$. All experiments were repeated twice. The adsorption amount of MB and MO were calculated as follows, Eq. 1:

$$
\text { Amount of adsorption }(\mathrm{Q})=\frac{\left(C_{o}-C_{t}\right) V}{m}
$$

$\mathrm{C}_{\mathrm{o}}$ is the initial dye concentration $(\mathrm{mg} / \mathrm{L})$ whereas $\mathrm{C}_{\mathrm{t}}$ is the dye concentration after adsorption, $\mathrm{V}$ dye volume ( $\mathrm{mL}$ ), m adsorbent mass (g) [3].

\section{Results}

Figure 1 shown that SEM images of unloaded and dye loaded of waste ash. A rough surface morphology appears in the SEM photographs of waste ash. The dye uptake capacity has increased because of surface characteristics [3-4]. After the adsorption, as seen in Figure 1.b, a large number of pores are filled with large amount of dyes.

\subsection{Effect of initial dye concentration}

According to the results, both $\mathrm{MB}$ and MO removal efficiency decreases whereas the amount adsorbed were increased with the increase in dye concentration (100-1200 mg/L). Similar results were found by Sait et al (2014). MB is adsorbed by volcanic ash in their study [5]. Figure 2. described that effect of initial concentration of dyes molecules on the adsorption amount. According to the the figure, the adsorption amount of dyes molecules increased with increasing initial dyes concentration then reach plateau value at higher concentration.

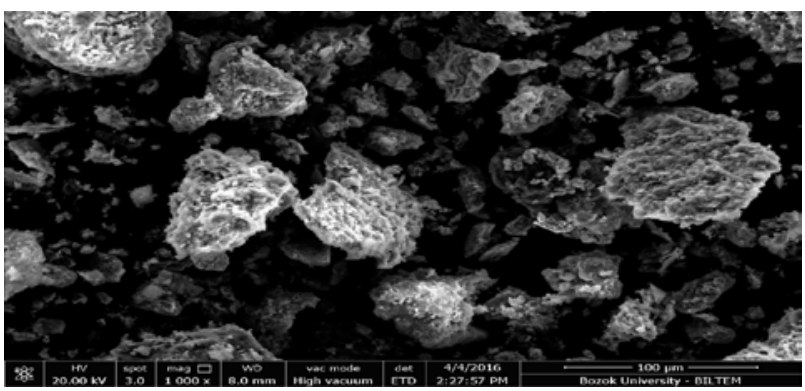

(a)

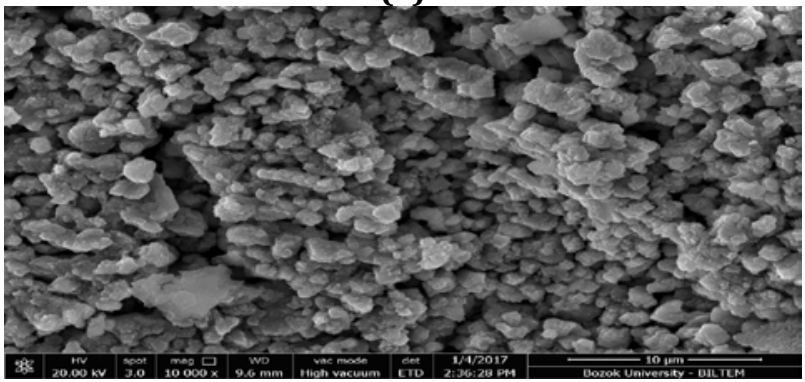

(b)

Figure 1. SEM images of unloaded (a) and dye loaded (b) waste ash

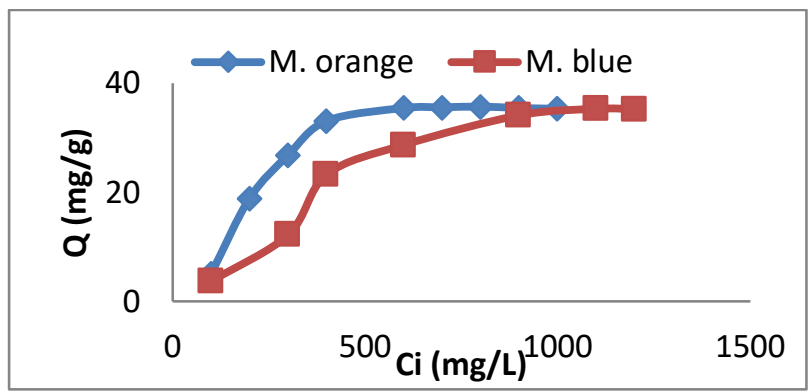

Figure 2. Effect of initial concentration of dyes molecules on the adsorption amount.

\subsection{Effect of $\mathrm{pH}$}

The adsorption capacity as function of the initial $\mathrm{pH}$ value was studied at a fix concentration $100 \mathrm{mg} / \mathrm{L}$, over a $\mathrm{pH}$ range from 2.6 to 10 . The adsorption capacity of the waste ash was higher under acidic conditions in Fig 2. Maximum adsorbent quantity of $5.112 \mathrm{mg} / \mathrm{g}$ was achieved at $\mathrm{pH} 5$ and minimum adsorbent quantity of $1.33 \mathrm{mg} / \mathrm{g}$ was obtained at $\mathrm{pH}=10$ for $\mathrm{MO}$. In addition to, maximum adsorbent quantity of $9.511 \mathrm{mg} / \mathrm{g}$ was achieved at $\mathrm{pH} 4$ and minimum adsorbed quantity of $2.51 \mathrm{mg} / \mathrm{g}$ was obtained at $\mathrm{pH}=2.6$ for MB. Saha et al (2010) studied adsorption of methyl orange onto chitosan. They found the most suitable $\mathrm{pH}$ is among the observed $\mathrm{pH}$ ranging from 4.0 to 9.0 [6]. Figure 3 shows effect of 
$\mathrm{pH}$ on $\mathrm{MB}$ and MO removal isotherm of dye adsorption. The adsorption increased with the increase of $\mathrm{pH}$ from 4 to 5 . After that it decreased with the increase of $\mathrm{pH} n$ then reached a plateau value.

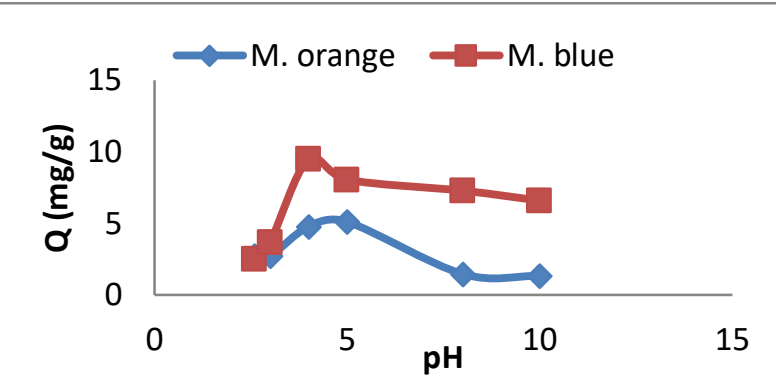

Figure 3. Effect of $\mathrm{pH}$ on $\mathrm{MB}$ and MO Removal Isotherm Of Dye Adsorption

\subsection{Effect of contact time}

The effect of contact time on adsorption of both MB and MO were investigated and the results were shown in Figures 4 and 5. Figure 4 shows variation of specific adsorption with time for MB. It shows that the waste ash has a high initial adsorption rate for dyes.

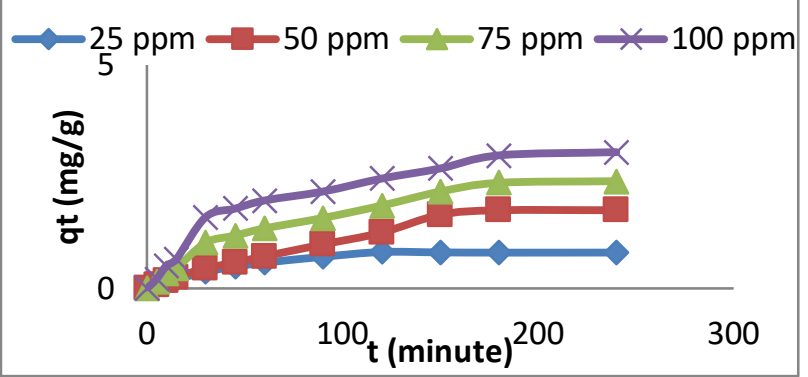

Figure 4. Variation of specific adsorption with time for $\mathrm{MB}$ $\left(\mathrm{W}=0.3 \mathrm{~g}, \mathrm{pH}=4, \mathrm{~V}=30 \mathrm{~mL}, \mathrm{~T}=25^{\circ} \mathrm{C}\right)$

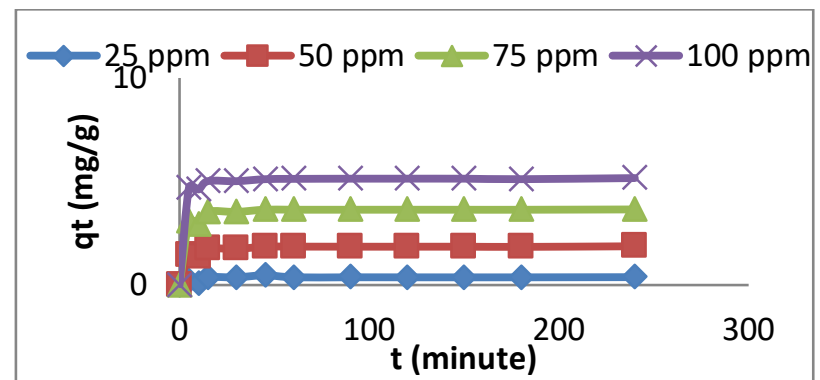

Figure 5. Variation of specific adsorption with time for various initial dye concentrations for various $M$. orange concentrations $\left(\mathrm{W}=0.3 \mathrm{~g}, \mathrm{pH}=5, \mathrm{~V}=30 \mathrm{~mL}, \mathrm{~T}=25^{\circ} \mathrm{C}\right.$ )

\subsection{Adsorption isotherms}

The adsorption of MB and MO onto waste ash was applied to Langmuir, Freundlich and DubininRadushkevich (D-R) Isotherm Model (298 K). The three models constants and correlation coefficients for adsorption of MB and MO are shown in Table 1. $E_{a}$ (energy) is useful for estimating the type of adsorption [7-8]. According to Table 1., estimated values of adsorption energy, Ea, was calculated from the D-R isotherm, for both MB and MO and waste ash systems were found to be $0.015 \mathrm{~kJ} \mathrm{~mol}^{-1}, 0.091 \mathrm{~kJ}$ $\mathrm{mol}^{-1}$ at room temperature respectively which implies that adsorption of both MB and MO on waste ash $(0.3 \mathrm{~g})$ is by physical adsorption.

Table 1. Isotherm parameters obtained from equilibrium models

\begin{tabular}{cccc}
\hline Langmuir & $\begin{array}{c}\text { Parameter } \\
\text { (unit) }\end{array}$ & $\begin{array}{c}\text { Methylene } \\
\text { blue }\end{array}$ & $\begin{array}{c}\text { Methyl } \\
\text { orange }\end{array}$ \\
\hline & $\mathrm{K}_{\mathrm{L}}(\mathrm{L} / \mathrm{g})$ & 0.323 & 15.243 \\
& $\mathrm{a}_{\mathrm{L}}(\mathrm{L} / \mathrm{mg})$ & $7.881^{*} 10^{-3}$ & 0.428 \\
Qmax(mg/g) & 40.983 & 35.614 \\
& $\mathrm{R}^{2}$ & 0.9988 & 0.9998 \\
\hline Freundlich & $\mathrm{n}_{\mathrm{F}}$ & 3.782 & 31.847 \\
Isotherm & $\mathrm{K}_{\mathrm{F}}$ & 6.153 & 29.302 \\
& $\mathrm{R}^{2}$ & 0.970 & 0.780 \\
\hline Dubinin- & $\mathrm{q}_{\mathrm{m}}$ & 35.103 & 35.591 \\
Radushkevich & $\mathrm{E}_{\mathrm{a}}$ & 0.015 & 0.091 \\
& $\mathrm{R}^{2}$ & 0.9396 & 0.9784 \\
\hline
\end{tabular}

Comparison of adsorption capacity of MB and MO onto some adsorbent in literature was given Table 2 .

Table 2. Comparison of adsorption capacity of MB and MO onto some adsorbent in literature

\begin{tabular}{|c|c|c|c|}
\hline Adsorbent & Dye & $\mathrm{Q}_{\max }(\mathrm{mg} / \mathrm{g})$ & References \\
\hline $\begin{array}{l}\text { Oil Shale } \\
\text { Ash }\end{array}$ & MB & 250 & [9] \\
\hline $\begin{array}{l}\text { Baggase } \\
\text { bottom ash }\end{array}$ & MB & 142.54 & [10] \\
\hline Fly ash & MB & 2.85 & [10] \\
\hline $\begin{array}{c}\text { Cow dung } \\
\text { ash }\end{array}$ & MB & 5.31 & [10] \\
\hline $\begin{array}{c}\text { Coal fly } \\
\text { ash }(0.01 \\
\mathrm{NaCl})\end{array}$ & MB & 16.6 & [11] \\
\hline $\begin{array}{l}\text { Coal fly } \\
\text { ash }\end{array}$ & MB & 12.7 & [11] \\
\hline $\begin{array}{c}\text { Bioler fly } \\
\text { ash }\end{array}$ & MO & 249.9 & [12] \\
\hline Waste ash & MB & 40.983 & This study \\
\hline Waste ash & MO & 35.614 & This study \\
\hline
\end{tabular}

Figure 6 shows Langmuir adsorption parameters for methylene blue and methyl orange. The adsorption behavior of waste ash fit Langmuir Model.

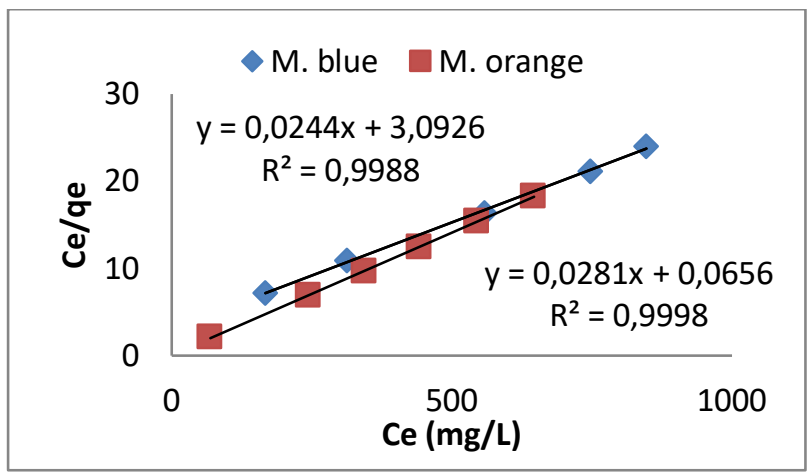

Figure 6. Langmuir isotherm parameters for MB and MO. 


\subsection{Kinetic study}

Lagergren-first-order model, pseudo-second-order kinetic model and intraparticle diffusion model were used to evaluate adsorption kinetics. Figures 7 and 8 represents pseudo second order rate plot for $\mathrm{MO}$ and MB respectively. The system was adjusted to a pseudo second order kinetic model.

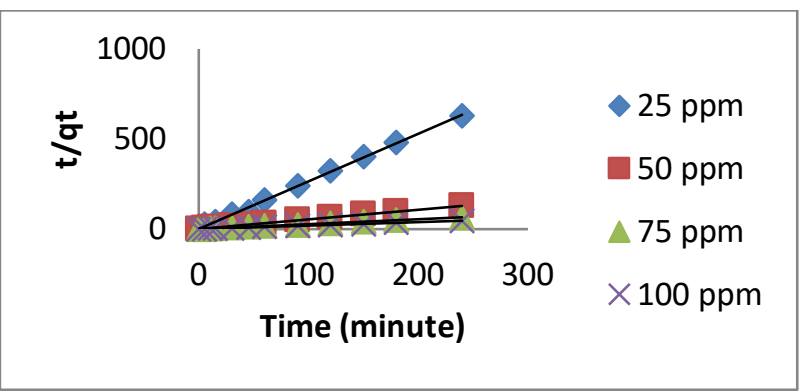

Figure 7. Pseudo second order kinetic model for methyl orange

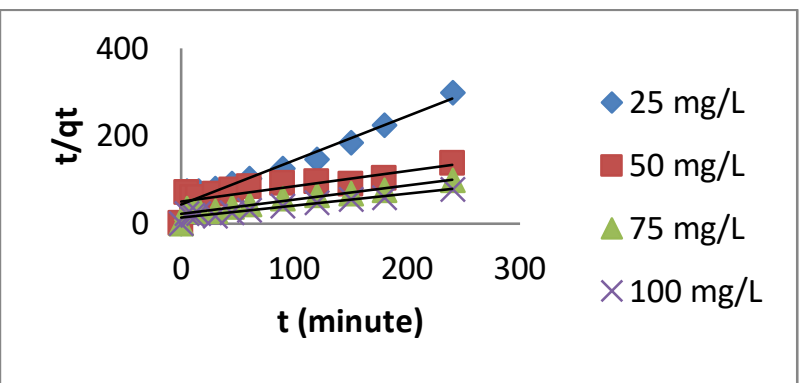

Figure 8. Pseudo second order kinetic model for methylene blue

\subsection{Studies of reusability}

Acid solution (5 $\left.\mathrm{M} \mathrm{HNO}_{3}\right)$ was used regeneration for waste ash, after that waste ash was used in dyes removal by adsorption. Waste ash is dried. Acid solution $\left(5 \mathrm{M} \mathrm{HNO}_{3}\right)$ are added $(30 \mathrm{~mL})$ in a conical flask. Then the solution were shaken for $24 \mathrm{~h}$. The waste ash were filtered and washed with distilled water until reach neutral $\mathrm{pH}$. Waste ash reaching neutral $\mathrm{pH}$ was used in desorption experiments. Same procedure was repeated five times. Methylene Blue adsorption capacity of waste ash after adsorption/desorption cycle $\left(\mathrm{Ci}=100 \mathrm{ppm}, \mathrm{T}=25^{\circ} \mathrm{C}\right.$, $\mathrm{t}=1 \mathrm{~h} \mathrm{pH}=4$ ) was shown in Figure 9. M. orange adsorption capacity of waste ash after adsorption/desorption cycle $\left(\mathrm{Ci}=100 \mathrm{ppm}, \mathrm{T}=25{ }^{\circ} \mathrm{C}\right.$, $\mathrm{t}=1 \mathrm{~h} \mathrm{pH=5}$ ) was shown in Figure 10.

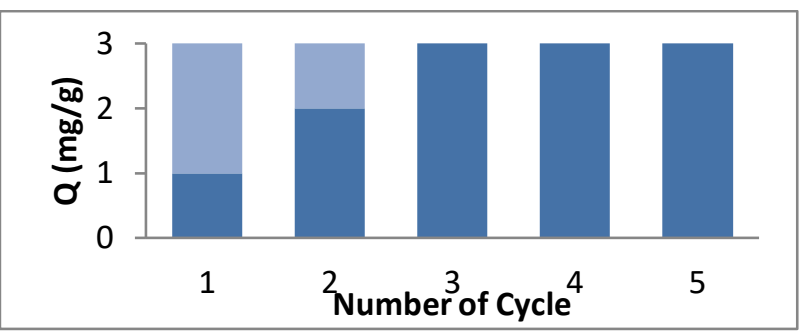

Figure 9. Methylene Blue adsorption capacity of waste ash after adsorption/desorption cycle $\left(\mathrm{Ci}=100 \mathrm{ppm}, \mathrm{T}=25^{\circ} \mathrm{C}\right.$, $\mathrm{t}=1 \mathrm{~h} \mathrm{pH}=4$ )

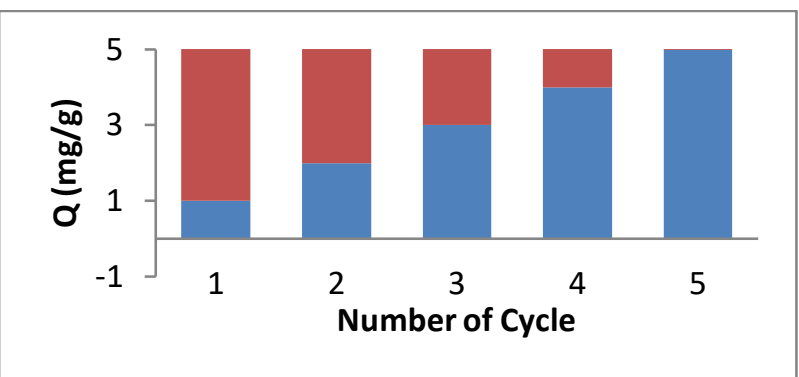

Figure 10. M. orange adsorption capacity of waste ash after adsorption/desorption cycle $\left(\mathrm{Ci}=100 \mathrm{ppm}, \mathrm{T}=25{ }^{\circ} \mathrm{C}, \mathrm{t}=1 \mathrm{~h}\right.$ $\mathrm{pH}=5$ )

\section{Discussion and Conclusion}

The adsorption of MB and MO on waste ash has been studied. The equilibrium experiments results shown prosperous adsorption and were better fit by Langmuir model in compared to the other models. Scanning electron microscopy (SEM) of the waste ash represent surface morphology which made it clear that waste ash is a good adsorbent. The pseudosecond order kinetic model equation was well described for kinetics (Higher $\mathrm{R}^{2}$ ). The regeneration of waste ash without losing its original activity is found at least five cycles.

\section{References}

[1] Turabik, M. 2008. Adsorption of basic dyes from single and binary component systems onto bentonite: Simultaneous analysis of Basic Red 46 and Basic Yellow 28 by first order derivative spectrophotometric analysis method. Journal of Hazardous Materials, 158(2011), 52-64.

[2] Fernandez, M. E., Nunell, G. V., Bonelli, P. R., \& Cukierman, A. L. 2012. Batch and dynamic biosorption of basic dyes from binary solutions by alkaline-treated cypress cone chips. Bioresource Technology, 106(2012), 55-62.

[3] Albadarin, A. B., 2015. Mangwandi, Mechanisms of Alizarin Red $S$ and Methylene blue biosorption onto olive stone by-product: Isotherm study in single and binary systems, J. Environ. Manag. 164 (2015), 86-93.

[4] Ezechi, E. H., Kutty, S.R.b.M., Malakahmad, A., Isa, M.H. 2015. Characterization and optimization of effluent dye removal using a new low cost adsorbent: Equilibrium, kinetics and thermodynamic study, Process Saf. Environ. Prot. 98(2015), 16-32.

[5] Said, A., Hakim, M. S. Rohyami, Y., 2014. The Effect of Contact Time and pH on Methylene Blue Removal by Volcanic Ash. International Conference on Chemical, Biological, and Environmental Sciences (ICCBES'14) May 12-13, 2014 Kuala Lumpur (Malaysia) 1002-1005.

[6] Saha, T. K., Bhoumik, N. C., Karmaker, S., Ahmed, M. G., Ichikawa, H., Fukumori, Y., 2010. Adsorption of Methyl Orange onto Chitosan from 
Aqueous Solution. J. Water Resource and Protection. 2(2010), 898-906.

[7] Mobasherpour, I., Salahi, E., Pazouki, M., 2012. Comparative of the removal of $\mathrm{Pb}^{+2}, \mathrm{Cd}^{+2}$ and $\mathrm{Ni}^{+2}$ by nano crystallite hydroxyapatite from aqueous solutions: Adsorption Isotherm Study. Arabian Journal Of Chemistry, 5(2012), 439-446.

[8] Chowdhury, S., Chakrabortyi, S., Saha, P., 2011. Biosorption of Basic Green 4 From Aquaeous Solution By Ananas Comosus (pineapple) leaf powder. Colloids and Surface B: Biointerfaces, 84(2011), 520.

[9] Zengying Z., Jiangyan Y., Meng F., La S., Zhaohui l., 2014. Removal of Methylene Blue from Aqueous Solution by Using Oll Shale Ash. Oil Shale, 31(2), 161-173.

[10] Kumar, K.V., 2002. Adsorption Isotherm for Basic Dye Onto Low Cost Adsorbents, Res. J. Chem. Environ. 6 (4), 61-65.

[11] Wang, S., Ma, Q., Zhu, Z. H., 2008. Characteristics of Coal Fly Ash and Adsorption Application, Fuel, 87, 3469-3473.

[12] Okoronkwo, N. E., Igwe, J. C., Uruakpa, H., N., 2008. Dye Removal From Waste Water by Adsorption Onto Boiler Fly Ash, Terrestrial and Aquatic Environmental Toxicology, 2(1)44-48. 